\title{
Sphingomonas oligophenolica sp. nov., a halo- and organo-sensitive oligotrophic bacterium from paddy soil that degrades phenolic acids at low concentrations
}

\author{
Correspondence \\ Hiroyuki Ohta \\ hohta@mx.ibaraki.ac.jp
}

\author{
Hiroyuki Ohta, ${ }^{1}$ Reiko Hattori, ${ }^{2}$ Yuuji Ushiba, ${ }^{1}$ Hisayuki Mitsui, ${ }^{3}$ Masao Ito, ${ }^{4}$ \\ Hiroshi Watanabe, ${ }^{5}$ Akira Tonosaki ${ }^{6}$ and Tsutomu Hattori ${ }^{2}$
}

\author{
${ }^{1}$ Department of Bioresource Science, Ibaraki University College of Agriculture, Ami-machi, \\ Ibaraki 300-0393, Japan \\ ${ }^{2}$ Attic Laboratory, Aoba-ku, Sendai 980-0813, Japan \\ ${ }^{3}$ Graduate School of Life Science, Tohoku University, Aoba-ku, Sendai 980-8577, Japan \\ ${ }^{4}$ Faculty of Agriculture, Nagoya University, Chikusa-ku, Nagoya 464-8601, Japan \\ ${ }^{5,6}$ Departments of Nursing ${ }^{5}$ and Anatomy ${ }^{6}$, Yamagata University School of Medicine, \\ Yamagata, Japan
}

\begin{abstract}
The taxonomic position of a halo- and organo-sensitive, oligotrophic soil bacterium, strain $\mathrm{S} 213^{\top}$, was investigated. Cells were Gram-negative, non-motile, strictly aerobic, yellow-pigmented rods of short to medium length on diluted nutrient broth. When $0 \cdot 1-0.4 \%(\mathrm{w} / \mathrm{v}) \mathrm{NaCl}$ was added to diluted media composed of peptone and meat extract, growth was inhibited with increasing $\mathrm{NaCl}$ concentration and the cells became long aberrant forms. When $6 \mathrm{mM} \mathrm{CaCl}_{2}$ was added, the cells grew quite normally and aberrant cells were no longer found at $0.1-0.5 \%$ $(w / v) \mathrm{NaCl}$. Chemotaxonomically, strain $\mathrm{S} 213^{\top}$ contains chemical markers that indicate its assignment to the Sphingomonadaceae: the presence of ubiquinone Q-10 as the predominant respiratory quinone, $\mathrm{C}_{18: 1}$ and $\mathrm{C}_{16: 0}$ as major fatty acids, $\mathrm{C}_{14: 0} 2-\mathrm{OH}$ as the major 2-hydroxy fatty acid and sphingoglycolipids. $16 \mathrm{~S}$ rRNA gene sequence analysis indicated that strain $S 213^{\top}$ belongs to the genus Sphingomonas, exhibiting high sequence similarity to the 16S rRNA gene sequences of Sphingomonas mali IFO $15500^{\top}(98 \cdot 3 \%)$, Sphingomonas pruni IFO $15498^{\top}$ (98.0\%), Sphingomonas asaccharolytica IFO $15499^{\top}(97.9 \%)$ and Sphingomonas echinoides DSM $1805^{\top}(97 \cdot 8 \%)$. The results of DNA-DNA hybridization experiments and its phenotypic characteristics clearly distinguished the strain from its nearest neighbours and demonstrate that strain $S 213^{\top}$ represents a novel Sphingomonas species, for which the name Sphingomonas oligophenolica sp. nov. is proposed. The type strain is $S 213^{\top}\left(=\mathrm{JCM} 12082^{\top}=\mathrm{CIP} 107926^{\top}\right)$.
\end{abstract}

In very early studies on soil bacterial populations, soil microbiologists noted that the best results of plate counting were obtained on media containing low levels of organic nutrients (e.g. Conn, 1914). The low organic content of the media undoubtedly holds in check certain rapidly growing organisms that would prevent the growth of the more numerous but more slowly growing bacteria. In the 1970 s and 1980s, a series of studies by Hattori and co-workers demonstrated that a number of soil bacteria isolated on low-nutrient media were not only slow growing but also

\footnotetext{
The GenBank/EMBL/DDBJ accession number for the 16S rRNA gene sequence of Sphingomonas oligophenolica $S 213^{\top}$ is AB018439.

Micrographs of the fine structures of strain $S 213^{\top}$ are available as supplementary material in IJSEM Online.
}

highly sensitive to mineral salts and organic compounds (Hattori, 1976; Hattori \& Hattori, 1980; Ohta \& Hattori, 1980; Suwa \& Hattori, 1984; Whang \& Hattori, 1988). Such low-nutrient bacteria were classified as members of oligotrophic groups by their ability to grow on media containing trace amounts of organic nutrients (Ohta \& Hattori, 1983a; Suwa \& Hattori, 1984). Although members of the genus Arthrobacter (class Actinobacteria) are widespread in soil and are assumed to be examples of soil oligotrophic bacteria (Williams, 1985), a majority of oligotrophic isolates from paddy field soils in Japan belonged to the 'Alphaproteobacteria', 'Betaproteobacteria' or Cytophaga-FlexibacterBacteroides group (Mitsui et al., 1997a).

A soil bacterium, strain $\mathrm{S} 213^{\mathrm{T}}$, was isolated on a lownutrient medium from Kashimadai paddy soil near Sendai 
in Japan (Hattori, 1976), and its growth was severely suppressed by full-strength nutrient broth (Hattori \& Hattori, 1980). Strain S213 ${ }^{\mathrm{T}}$ was tentatively identified as a Gram-negative aerobic bacterium close to Pseudomonas paucimobilis (now Sphingomonas paucimobilis) (Ohta, 1982). Strain $S 213^{T}$ is able to grow rapidly with low concentrations $(<1 \mathrm{mM})$ of lignin-related ferulic acid, but growth is inhibited at concentrations above this (Ohta, 2001). Because ferulic acid concentrations in normal paddy soils are low (Shindo \& Kuwatsuka, 1977), it seems likely that strain $\mathrm{S} 213^{\mathrm{T}}$-related organisms play an important role in the process of lignin degradation. With respect to the salt sensitivity of soil oligotrophs, it was reported that a drastic change in the outer membrane structure of a soil bacterium, strain S34, related to the genus Deinococcus was induced by $0 \cdot 2-0 \cdot 4 \%(\mathrm{w} / \mathrm{v}) \mathrm{NaCl}$, and that this change in structure was relieved by $6 \mathrm{mM} \mathrm{CaCl}$ and induced by 1 mM EGTA (Mitsui et al., 1997b). The aim of the present study was to determine the taxonomic relationships between strain $\mathrm{S} 213^{\mathrm{T}}$ and related species in the Sphingomonas group, using phenotypic, chemotaxonomic and genomic analyses. In addition, we examined the effect of $\mathrm{NaCl}$ and $\mathrm{CaCl}_{2}$ on the cell morphology and ultrastructure of strain $\mathrm{S} 213^{\mathrm{T}}$ to show its dependence on calcium.

Strain $\mathrm{S} 213^{\mathrm{T}}$ was maintained as a stab culture in a 100 -fold dilution $\left(10^{-2} \mathrm{NB}\right)$ of the nutrient broth $(\mathrm{NB})$ containing $0 \cdot 4 \%(\mathrm{w} / \mathrm{v})$ agar at room temperature. NB comprised $1 \%$ $(\mathrm{w} / \mathrm{v})$ meat extract (Kyokuto Seiyaku), $1 \%(\mathrm{w} / \mathrm{v})$ polypeptone (Nihon Seiyaku) and $0.5 \%(\mathrm{w} / \mathrm{v}) \mathrm{NaCl} . \mathrm{pH}$ was adjusted to $7 \cdot 0$ with $1 \mathrm{M} \mathrm{NaOH}$. Cellular morphologies were examined after growth in the late-exponential phase at $27^{\circ} \mathrm{C}$ by phase-contrast microscopy and electron microscopy (Mitsui et al., 1997b). The following liquid media were used: (1) $10^{-2} \mathrm{PM}$ (peptone and meat extract), which comprised $0.01 \%(\mathrm{w} / \mathrm{v})$ each of peptone (Kyokuto Seiyaku) and meat extract; (2) $10^{-2} \mathrm{PM}$ supplemented with $0 \cdot 1,0 \cdot 2$, $0 \cdot 3,0.4$ or $0.5 \%(\mathrm{w} / \mathrm{v}) \mathrm{NaCl}$; and (3) $10^{-1} \mathrm{PM}$, which comprised $0 \cdot 1 \%(\mathrm{w} / \mathrm{v})$ each of peptone and meat extract. $\mathrm{CaCl}_{2}$ was added to media 2 and 3 to a final concentration of $6 \mathrm{mM}$ to determine the effect of calcium ions.

Heat resistance was examined with 28-day-old cultures on $10^{-2} \mathrm{NB}$ semi-solid agar medium by testing viability after standing for $10 \mathrm{~min}$ at $80^{\circ} \mathrm{C}$. Cultures surviving the heat treatment were regarded as spore-formers. To determine the ability of cells to grow anaerobically, cultures of $10^{-2} \mathrm{NB}$ or $10^{-2} \mathrm{NB}$ with $0 \cdot 2 \%(\mathrm{w} / \mathrm{v})$ glucose both in the presence and in the absence of $0 \cdot 1 \%(\mathrm{w} / \mathrm{v}) \mathrm{NaNO}_{3}$ were incubated in an atmosphere containing $80 \%(\mathrm{v} / \mathrm{v}) \mathrm{N}_{2}, 10 \%(\mathrm{v} / \mathrm{v}) \mathrm{H}_{2}$ and $10 \%(\mathrm{v} / \mathrm{v}) \mathrm{CO}_{2}$.

Substrate utilization profile was tested in a 1000-fold diluted NB $\left(10^{-3} \mathrm{NB}\right)$ liquid medium supplemented with L-arabinose, D-xylose, D-glucose, D-galactose, D-mannose, D-fructose, cellobiose, maltose, lactose, raffinose, acetic acid, DL-lactic acid, gluconic acid, pyruvic acid, 2-oxoglutaric acid, citric acid, succinic acid, L-malic acid or methanol. All compounds were sterilized by filtration and were added to autoclaved $10^{-3} \mathrm{NB}$ medium. Sugars were added at a concentration of $0.1 \%(\mathrm{w} / \mathrm{v})$, organic acids at $0.03 \%$ $(\mathrm{w} / \mathrm{v})$ and methanol at $50 \mathrm{mM}$. Growth was measured over a 2-week period and utilization was assessed by comparing the growth both in the presence and in the absence of an added compound. To test the degradation profile of aromatic compounds, strain $\mathrm{S} 213^{\mathrm{T}}$ was grown at $30^{\circ} \mathrm{C}$ in a 10-fold dilution of Difco nutrient broth supplemented with one of the following compounds $(1 \mathrm{mM})$ : benzoic acid, ferulic acid, $o-, m$ - and $p$-hydroxybenzoic acid, $o-, m$ and $p$-toluic acid, $o$ - and $p$-anisic acid, $o-, m$ - and $p$-cresol, cinnamic acid, $m$ - and $p$-coumaric acid, phenylacetic acid, phenol, vanillic acid or caffeic acid. Cultures were left for 10 days and degradation of a compound was judged by a change in the UV absorption spectrum. Organic acids including aromatic acids were prepared as sodium salts. Assay for hydrolysis of starch, gelatin and casein and tests for oxidase, catalase and nitrate reduction were carried out as described by Ohta \& Hattori (1983b).

Analyses of cellular fatty acids and isoprenoid quinones were performed as described by Komagata \& Suzuki (1987). For detection of hydroxy fatty acids, TLC (Kieselgel F-254, Merck) was employed with a solvent system of $n$-hexane and diethyl ether $(1: 1, \mathrm{v} / \mathrm{v})$. Fatty acid methyl ester analysis by GLC was carried out on a glass column $(5 \mathrm{~m})$ packed with $10 \%$ diethyleneglycol succinate using standard fatty acid methyl esters, as described by Ohta \& Hattori (1983b). Cellular lipids were analysed by the method of Hirai et al. (1995) using Sphingomonas paucimobilis JCM $7516^{\mathrm{T}}$ as the reference strain. For detection of alkalinestable glycolipids, the total extractable lipids were incubated in $1 \mathrm{M} \mathrm{KCl}$ and methanol $(2: 1, \mathrm{v} / \mathrm{v})$ for $2 \mathrm{~h}$ at $37^{\circ} \mathrm{C}$ and analysed by TLC with a solvent system composed of chloroform, methanol and water $(70: 30: 5$, by volume).

Isolation of DNA (Saito \& Miura, 1963) and determination of the DNA G $+\mathrm{C}$ content by the thermal denaturation method (Marmur \& Doty, 1962) followed standard procedures. DNA-DNA relatedness was estimated by a chemiluminescence DNA-DNA hybridization method with photobiotin-labelled probes in microplate wells, as described by Ezaki et al. (1989). For enzymic development, alkaline phosphatase-streptavidin conjugate (Vector) was used with CDP-Star (Tropix) as the substrate and chemiluminescence was measured on a Wallac 1420 ARVOsx multilabel counter.

The 16S rRNA gene sequence of strain $\mathrm{S} 213^{\mathrm{T}}$ was obtained by PCR amplification of genomic DNA using a universal primer set, and the nucleotide sequence (nucleotide positions 28-1390; Escherichia coli numbering) was determined as described by Hiraishi (1992). The DNA sequence was aligned with reference sequences of representative species of Sphingomonas sensu stricto, Novosphingobium, Sphingobium and Sphingopyxis. Multiple alignments, calculation of nucleotide substitution rates ( $K_{\text {nuc }}$ values) as described by Kimura (1980) and construction of a phylogenetic tree by the neighbour-joining method (Saitou 
\& Nei, 1987) were performed by using the CLUSTAL W program (Thompson et al., 1994). The robustness of tree topology was evaluated by a bootstrap analysis (1000 replications).

Strain $S 213^{\mathrm{T}}$ showed a range of phenotypic properties typical of members of the genus Sphingomonas (Yabuuchi et al., 1990; Takeuchi et al., 2001). Cells are strictly aerobic, Gram-negative, non-sporulating and catalase-positive rods $(0 \cdot 4-0.6 \times 1 \cdot 0-1 \cdot 5 \mu \mathrm{m})$. Colonies are pale yellow on $10^{-2}$ NB agar and yellow on a 10 -fold diluted NB agar medium. When ferulate-limited chemostat-cultured cells (Ohta, 2001) were used for analysis of acetone-soluble pigments (70 mg wet cells with $400 \mu \mathrm{l}$ acetone), the spectrum of the acetone extract had peaks at 454 and $482 \mathrm{~nm}$ and a shoulder at $431 \mathrm{~nm}$. Strain $\mathrm{S} 213^{\mathrm{T}}$ grew at 4, 10, 25, 30 and $37^{\circ} \mathrm{C}$ but not at $42^{\circ} \mathrm{C}$ in $10^{-2} \mathrm{NB}$ liquid cultures.

When grown in $10^{-2} \mathrm{PM}$, strain $\mathrm{S} 213^{\mathrm{T}}$ clearly shows the typical cell wall structure of Gram-negative bacteria, as recognized from the presence of the outer membrane and the peptidoglycan layer (see Fig. A available as supplementary material in IJSEM Online). When 20 phasecontrast microscopic fields, each containing 50-70 cells, were observed, the ratios of aberrant to normal cells in $10^{-2} \mathrm{PM}$ supplemented with $0,0 \cdot 1,0 \cdot 2$ and $0 \cdot 3 \%(\mathrm{w} / \mathrm{v})$ $\mathrm{NaCl}$ were 0 (Fig. 1A), $0 \cdot 23,0 \cdot 64$ and $0 \cdot 83$, respectively. With increasing $\mathrm{NaCl}$ concentration, cells became longer and, at $0 \cdot 4 \%(\mathrm{w} / \mathrm{v}) \mathrm{NaCl}$, all cells resembled long filaments and seemed to be aberrant in form (Fig. 1B). At $0.5 \%(\mathrm{w} / \mathrm{v}) \mathrm{NaCl}$, faint ghost-like filaments were observed exclusively. When cells were grown in $10^{-1} \mathrm{PM}$, they became longer and aberrant but less remarkably so (data not shown). Calcium significantly relieved this effect of $\mathrm{NaCl}$ as in the case of strain S34, a highly halo-sensitive soil bacterium (Mitsui et al., 1997b). When $6 \mathrm{mM} \mathrm{CaCl}_{2}$ was added, cells of strain $\mathrm{S} 213^{\mathrm{T}}$ grew quite normally and the ratio of aberrant to normal cells was 0 at every $\mathrm{NaCl}$ concentration tested $(0 \cdot 1-0 \cdot 5 \%, \mathrm{w} / \mathrm{v})$ in $10^{-2} \mathrm{PM}$ or in

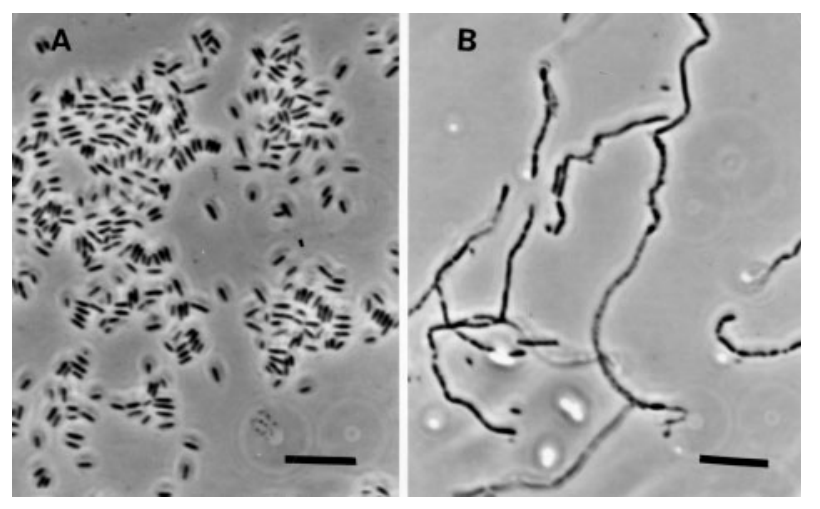

Fig. 1. Phase-contrast micrographs showing the effect of $\mathrm{NaCl}$ on cell morphology. (A) Cells grown in $10^{-2} \mathrm{PM}$; (B) cells grown in $10^{-2} \mathrm{PM}$ supplemented with $0.4 \%(\mathrm{w} / \mathrm{v}) \mathrm{NaCl}$. Bars, $5 \mu \mathrm{m}$.
$10^{-1} \mathrm{PM}$. In the presence of $0 \cdot 1 \%(\mathrm{w} / \mathrm{v}) \mathrm{NaCl}$, deposition of electron-dense particles between the outer and inner membranes became apparent (supplementary Figs B and $\mathrm{C}$ in IJSEM Online). With the addition of $0.4 \%(\mathrm{w} / \mathrm{v})$ $\mathrm{NaCl}$, three types of structural change were observed: (1) membrane-deposited particles were excluded from the cells (supplementary Fig. D), (2) membrane structure remained normal but division was inhibited (supplementary Fig. E), and (3) cell lysis occurred (supplementary Fig. D). These detrimental effects of $\mathrm{NaCl}$ on the cellular structure were not detected in the presence of $\mathrm{CaCl}_{2}$ (supplementary Fig. F).

Strain $\mathrm{S} 213^{\mathrm{T}}$ utilized some pentoses, hexoses, oligosaccharides and organic acids. Methanol was not utilized. The organism was able to degrade four phenolic acids (ferulic acid, $p$-hydroxybenzoic acid, $p$-coumaric acid and vanillic acid) of 20 aromatic compounds tested. The strain reduced nitrate to nitrite but denitrification was not detected. Other details relating to biochemical characteristics are included below in the species description. Diagnostic characteristics are shown in Table 1.

Chemotaxonomically, strain $S 213^{\mathrm{T}}$ contains chemical markers that support its assignment to the Sphingomonas sensu lato group. Cells contain ubiquinone Q-10 as the predominant respiratory quinone and have $\mathrm{C}_{18: 1}(56 \%$, mean of independent duplicate determinations), $\mathrm{C}_{16: 0}$ $(10 \%)$ and $\mathrm{C}_{16: 1}(6 \%)$ as major fatty acids and $\mathrm{C}_{14: 0}$ 2-OH (19\%) as the major 2-hydroxy fatty acid. Other fatty acids detected were $\mathrm{C}_{14: 0}(3 \%), \mathrm{C}_{17: 1}(1 \%)$ and $\mathrm{C}_{12: 0}$ $(<0.5 \%)$; the summed amount of unknown acids was $5 \%$. No visible spot of 3-hydroxy fatty acids was detected in TLC of the fatty acid methyl esters. When the total extractable lipid pattern of strain $S 213^{\mathrm{T}}$ on TLC was compared with that of Sphingomonas paucimobilis JCM $7516^{\mathrm{T}}$, three major spots of polar lipids of $R_{\mathrm{F}}$ values $0 \cdot 41$, 0.57 and 0.78 were found in common. Based on the results of polar lipid analysis by Yabuuchi et al. (1990), the major polar lipids of $R_{\mathrm{F}}$ values 0.57 and 0.78 corresponded to phosphatidyl ethanolamine and cardiolipin, respectively. In our preparation of polar lipids, the spot of phosphatidyl glycerol was not clearly detected in strain $\mathrm{S} 213^{\mathrm{T}}$. Mild alkaline hydrolysis of the total extractable lipids and subsequent TLC analysis revealed that the major lipid of $R_{\mathrm{F}}$ value 0.41 was an alkaline-stable glycolipid, probably glucuronosyl ceramide reported with Sphingomonas paucimobilis JCM $7516^{\mathrm{T}}$ by Yabuuchi et al. (1990). A minor spot of alkaline-stable glycolipid of $R_{\mathrm{F}}$ value 0.25 was also detected in strain $\mathrm{S} 213^{\mathrm{T}}$ but its relation to the glycolipids $\mathrm{GX}_{1}, \mathrm{GX}_{2}, \mathrm{GX}_{3}$ and $\mathrm{GL}^{\prime}$ of the Sphingomonas group (Yabuuchi et al., 1990) is currently unknown.

The 16S rRNA gene sequence (1306 bp) of strain S213 ${ }^{\mathrm{T}}$ was used for searches in the GenBank, EMBL and DDBJ databases by the FASTA program (Pearson \& Lipman, 1988). Strain $\mathrm{S} 213^{\mathrm{T}}$ is a member of the Sphingomonadaceae, most closely related to the genus Sphingomonas. Sequence similarity calculations indicated that the nearest relatives of the strain are Sphingomonas mali IFO $15500^{\mathrm{T}}(98 \cdot 3 \%)$, 
Table 1. Phenotypic characteristics of strain $S 213^{\top}$ and the type strains of nine phylogenetically related Sphingomonas species

Strains: 1, strain S213 ${ }^{\mathrm{T}}$ (this study); 2, S. echinoides DSM $1805^{\mathrm{T}}$ (Denner et al., 1999); 3, S. asaccharolytica IFO $15499^{\mathrm{T}}$ (Takeuchi et al., 1995); 4, S. mali IFO $15500^{\mathrm{T}}$ (Takeuchi et al., 1995); 5, S. pruni IFO $15498^{\mathrm{T}}$ (Takeuchi et al., 1995); 6, S. koreensis JSS26 ${ }^{\mathrm{T}}$ (Lee et al., 2001); 7, S. melonis DAPP-PG 224 ${ }^{\mathrm{T}}$ (Buonaurio et al., 2002); 8, S. aquatilis JSS7 ${ }^{\mathrm{T}}$ (Lee et al., 2001); 9, S. adhaesiva GIFU 11458 ${ }^{\mathrm{T}}$ (Yabuuchi et al., 1990); 10, S. paucimobilis GIFU $2395^{\mathrm{T}}$ (type strain for the type species of the genus, Yabuuchi et al., 1990). ND, No data; + , positive reaction; - , negative reaction; $\mathrm{W}$, weakly positive reaction. All strains are positive for utilization of glucose and maltose and contain $\mathrm{C}_{14: 0}$ 2-OH as the major 2-hydroxy fatty acid.

\begin{tabular}{|c|c|c|c|c|c|c|c|c|c|c|}
\hline Characteristic & 1 & 2 & 3 & 4 & 5 & 6 & 7 & 8 & 9 & 10 \\
\hline Motility & - & + & + & + & + & + & - & + & + & + \\
\hline Reduction of nitrate & + & $+^{*}$ & $+^{*}$ & $+^{*}$ & $+^{*}$ & - & - & - & - & + \\
\hline Hydrolysis of gelatin & + & - & - & - & + & - & - & - & - & + \\
\hline Acid production from glucose & - & - & $\mathrm{W}$ & - & $\mathrm{W}$ & W & + & + & - & + \\
\hline \multicolumn{11}{|l|}{ Assimilation of: } \\
\hline Acetate & + & - & - & - & $\mathrm{W}$ & ND & ND & ND & - & ND \\
\hline L-Arabinose & + & + & $\mathrm{W}$ & $\mathrm{W}$ & + & - & + & + & - & + \\
\hline Cellobiose & + & $\mathrm{W}$ & - & + & + & ND & + & $\mathrm{ND}$ & + & + \\
\hline D-Fructose & - & - & - & $\mathrm{W}$ & + & ND & + & ND & + & + \\
\hline D-Galactose & + & + & - & + & + & $\mathrm{ND}$ & + & $\mathrm{ND}$ & - & + \\
\hline Gluconate & + & + & - & + & + & - & - & - & - & - \\
\hline DL-Lactate & + & - & - & - & - & $\mathrm{ND}$ & + & $\mathrm{ND}$ & - & - \\
\hline Lactose & + & ND & $\mathrm{W}$ & + & + & ND & + & ND & + & + \\
\hline L-Malate & - & + & - & - & $\mathrm{W}$ & + & + & - & + & + \\
\hline D-Mannose & + & - & $\mathrm{W}$ & + & + & - & + & - & + & + \\
\hline Raffinose & + & $\mathrm{ND}$ & - & + & - & ND & - & ND & - & + \\
\hline D-Xylose & + & - & + & + & + & ND & + & ND & - & + \\
\hline \multicolumn{11}{|l|}{ Major 2-hydroxy fatty acid: } \\
\hline $\mathrm{C}_{15: 0} 2-\mathrm{OH}$ & - & - & + & + & + & + & - & - & - & - \\
\hline $\mathrm{C}_{16: 0} 2-\mathrm{OH}$ & - & - & - & - & - & + & - & - & - & - \\
\hline
\end{tabular}

${ }^{\star}$ Data from Takeuchi et al. (2001).

Sphingomonas pruni IFO $15498^{\mathrm{T}}(98 \cdot 0 \%)$, Sphingomonas asaccharolytica IFO $15499^{\mathrm{T}}(97 \cdot 9 \%)$ and Sphingomonas echinoides DSM $1805^{\mathrm{T}}(97 \cdot 8 \%)$. Similarities of 95 to $97 \%$ were found to the 16S rRNA gene sequences of Sphingomonas melonis DAPP-PG $224^{\mathrm{T}}$ (96.9\%), Sphingomonas adhaesiva GIFU $11458^{\mathrm{T}}(96 \cdot 1 \%)$, Sphingomonas sanguinis IFO $13937^{\mathrm{T}}(95 \cdot 4 \%)$ and Sphingomonas parapaucimobilis JCM $7510^{\mathrm{T}}(95 \cdot 6 \%)$. Construction of a $16 \mathrm{~S}$ rRNA gene sequence-based phylogenetic tree indicated that strain S2 $13^{\mathrm{T}}$ branched with Sphingomonas echinoides DSM $1805^{\mathrm{T}}$ with high bootstrap support (Fig. 2).

The DNA G $+\mathrm{C}$ content of strain $\mathrm{S} 213^{\mathrm{T}}$ was $64 \cdot 2 \mathrm{~mol} \%$ and fell within the range $(62-68 \mathrm{~mol} \%)$ reported for the genus Sphingomonas (Takeuchi et al., 2001). DNA-DNA relatedness between strain $S 213^{\mathrm{T}}$ and strains of phylogenetically related Sphingomonas species was analysed. Strain $S 213^{\mathrm{T}}$ showed very low DNA-DNA relatedness values to its closest phylogenetic neighbours, Sphingomonas echinoides NBRC $15742^{\mathrm{T}}$ (= DSM 1805 ${ }^{\mathrm{T}}$ ) (10\%), Sphingomonas asaccharolytica IFO $15499^{\mathrm{T}}(10 \%)$, Sphingomonas mali IFO $15500^{\mathrm{T}}(12 \%)$ and Sphingomonas pruni IFO $15498^{\mathrm{T}}(6 \%)$, whereas relatedness values of 22,17 and $16 \%$ were found between Sphingomonas echinoides DSM $1805^{\mathrm{T}}$ and the type strains of Sphingomonas pruni, Sphingomonas asaccharolytica and Sphingomonas mali, respectively.

Takeuchi et al. (2001) have shown that polyamine patterns and nitrate reduction provide good diagnostic markers for differentiation of Sphingomonas, Sphingobium, Novosphingobium and Sphingopyxis species. Although polyamine was not analysed in this study, the assignment of strain $\mathrm{S} 213^{\mathrm{T}}$ to the genus Sphingomonas is supported by its phylogenetic position and nitrate reduction data. As shown in Table 1, strain $\mathrm{S} 213^{\mathrm{T}}$ can be clearly differentiated from other phylogenetically related Sphingomonas species on the basis of major 2-hydroxy fatty acids and several phenotypic characteristics. The genomic and phenotypic evidence presented here clearly indicate that strain $S 213^{\mathrm{T}}$ is representative of a novel species of the genus Sphingomonas, for which the name Sphingomonas oligophenolica sp. nov. is proposed.

\section{Description of Sphingomonas oligophenolica sp. nov.}

Sphingomonas oligophenolica (o.li.go.phe.no'li.ca. Gr. adj. oligos little, scanty; N.L. n. phenol phenol; N.L. fem. adj. 


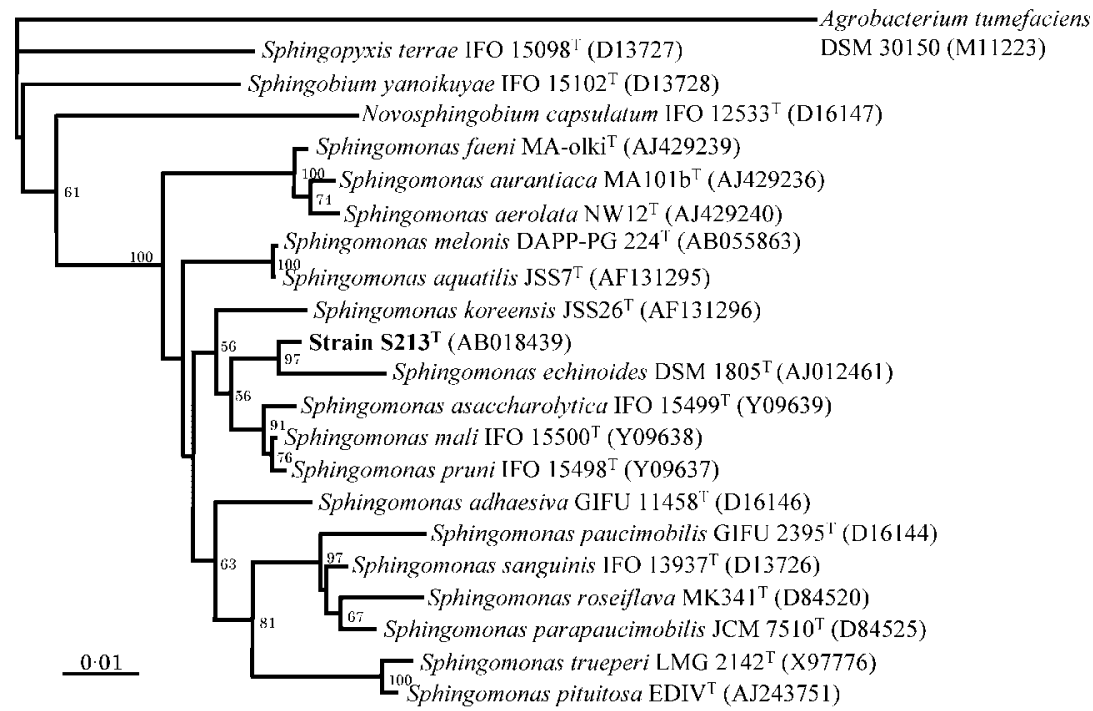

Fig. 2. Unrooted tree showing the phylogenetic relationships of strain $\mathrm{S} 213^{\top}$ and representative species of the genera Sphingomonas, Sphingobium, Novosphingobium and Sphingopyxis. The tree, constructed using the neighbour-joining method, was based on a comparison of a region corresponding to Escherichia coli positions 28-1390. Bootstrap values, expressed as a percentage of 1000 replications, are given at branching points. Bar, 0.01 nucleotide substitution rate $\left(K_{\text {nuc }}\right)$ unit. oligophenolica relating to small amounts of phenolic compounds).

Cells are Gram-negative, non-motile, non-sporulating rods $(0 \cdot 4-0 \cdot 6 \mu \mathrm{m}$ wide and $1 \cdot 0-1 \cdot 5 \mu \mathrm{m}$ long). Colonies are circular and convex with entire margins, pale yellow and pinpoint after 3 days incubation on a 100-fold diluted nutrient broth medium and yellow and $0 \cdot 6-0.8 \mathrm{~mm}$ in diameter after 3 days incubation on a 10 -fold diluted nutrient broth medium. Growth is suppressed slightly in the presence of $0 \cdot 1 \%(\mathrm{w} / \mathrm{v}) \mathrm{NaCl}$; this suppression is enhanced with increasing $\mathrm{NaCl}$ concentration in cultures. In the presence of $0.5 \%(\mathrm{w} / \mathrm{v}) \mathrm{NaCl}$ cells become faint ghost-like filaments. $\mathrm{NaCl}$-induced aberrant cell morphologies are significantly reduced by the addition of calcium $\left(6 \mathrm{mM} \mathrm{CaCl}_{2}\right)$. Able to grow at $4-37^{\circ} \mathrm{C}$ but not at $42^{\circ} \mathrm{C}$. Strictly aerobic, catalase-positive and oxidase-positive. Nitrate is reduced to nitrite but not to $\mathrm{N}_{2}$. Hydrolyses gelatin, but not starch or casein. Acid is not produced from glucose. Assimilates L-arabinose, D-xylose, D-glucose, D-galactose, D-mannose, cellobiose, maltose, lactose, raffinose, acetic acid, DL-lactic acid, gluconic acid, pyruvic acid, 2-oxoglutaric acid, ferulic acid, p-hydroxybenzoic acid, $p$-coumaric acid and vanillic acid. The following compounds are not utilized: D-fructose, citric acid, succinic acid, L-malic acid, benzoic acid, $o$ - and $m$-hydroxybenzoic acid, $o^{-}, m$ - and $p$-toluic acid, $o^{-}$and $p$-anisic acid, $o^{-}, m$ and $p$-cresol, cinnamic acid, $m$-coumaric acid, phenylacetic acid, phenol, caffeic acid and methanol. The major nonpolar fatty acids are $\mathrm{C}_{18: 1}$ and $\mathrm{C}_{16: 0}$, and the major 2hydroxy fatty acid is $\mathrm{C}_{14: 0}$ 2-OH. No 3-OH fatty acids are present. The major isoprenoid quinone is ubiquinone Q-10. Sphingoglycolipid is present. Acetone-soluble pigment is characterized by $\lambda_{\max }$ at 454 and $482 \mathrm{~nm}$. The DNA $\mathrm{G}+\mathrm{C}$ content is $64 \cdot 2 \mathrm{~mol} \%$.

The type strain, $\mathrm{S} 213^{\mathrm{T}}\left(=\mathrm{JCM} 12082^{\mathrm{T}}=\mathrm{CIP} 107926^{\mathrm{T}}\right.$ ), was isolated from paddy soil near Sendai in Japan.

\section{References}

Buonaurio, R., Stravato, V. M., Kosako, Y., Fujiwara, N., Naka, T., Kobayashi, K., Cappelli, C. \& Yabuuchi, E. (2002). Sphingomonas melonis sp. nov., a novel pathogen that causes brown spots on yellow Spanish melon fruits. Int J Syst Evol Microbiol 52, 2081-2087.

Conn, H. J. (1914). Culture media for use in the plate method of counting soil bacteria. N Y Agric Exp Stn Tech Bull 38, 3-34.

Denner, E. B. M., Kämpfer, P., Busse, H.-J. \& Moore, E. R. B. (1999). Reclassification of Pseudomonas echinoides Heumann 1962, 343 ${ }^{\mathrm{AL}}$, in the genus Sphingomonas as Sphingomonas echinoides comb. nov. Int J Syst Bacteriol 49, 1103-1109.

Ezaki, T., Hashimoto, Y. \& Yabuuchi, E. (1989). Fluorometric deoxyribonucleic acid-deoxyribonucleic acid hybridization in microdilution wells as an alternative to membrane filter hybridization in which radioisotopes are used to determine genetic relatedness among bacterial strains. Int J Syst Bacteriol 39, 224-229.

Hattori, T. (1976). Plate count of bacteria in soil on a diluted nutrient broth as a culture medium. Rep Inst Agric Res Tohoku Univ 27, 23-30.

Hattori, R. \& Hattori, T. (1980). Sensitivity to salts and organic compounds of soil bacteria isolated on diluted media. J Gen Appl Microbiol 26, 1-14.

Hirai, Y., Haque, M., Yoshida, T., Yokota, K., Yasuda, T. \& Oguma, K. (1995). Unique cholesteryl glucosides in Helicobacter pylori: composition and structural analysis. J Bacteriol 177, 5327-5333.

Hiraishi, A. (1992). Direct automated sequencing of $16 \mathrm{~S}$ rDNA amplified by polymerase chain reaction from bacterial cultures without DNA purification. Lett Appl Microbiol 15, 210-213.

Kimura, M. (1980). A simple method for estimating evolutionary rates of base substitutions through comparative studies of nucleotide sequences. J Mol Evol 16, 111-120.

Komagata, K. \& Suzuki, K. (1987). Lipid and cell-wall analysis in bacterial systematics. Methods Microbiol 19, 161-208.

Lee, J.-S., Kook, S. Y., Yoon, J.-H., Takeuchi, M., Pyun, Y.-R. \& Park, Y.-H. (2001). Sphingomonas aquatilis sp. nov., Sphingomonas koreensis sp. nov. and Sphingomonas taejonensis sp. nov., yellow-pigmented bacteria isolated from natural mineral water. Int J Syst Evol Microbiol 51, 1491-1498. 
Marmur, J. \& Doty, P. (1962). Determination of the base composition of deoxyribonucleic acid from its thermal denaturation temperature. J Mol Biol 5, 109-118.

Mitsui, H., Gorlach, K., Klee, H., Hattori, R. \& Hattori, T. (1997a). Incubation time and media requirements of culturable bacteria from different phylogenetic groups. J Microbiol Methods 30, 103-110.

Mitsui, H., Hattori, R., Watanabe, H., Tonosaki, A. \& Hattori, T. (1997b). $\mathrm{Na}^{+}$-induced structural change of a soil bacterium, S34, and $\mathrm{Ca}^{2+}$ requirement for preserving its original structure. J Bacteriol 179, 3350-3353.

Ohta, H. (1982). Biology of soil oligotrophic bacteria. $\mathrm{PhD}$ thesis, Tohoku University (in Japanese).

Ohta, H. (2001). Kinetic analysis of ferulic acid degradation by oligotrophic Sphingomonas sp. S213 during growth in batch and continuous cultures. Microb Environ 16, 9-17.

Ohta, H. \& Hattori, T. (1980). Bacteria sensitive to nutrient broth medium in terrestrial environments. Soil Sci Plant Nutr 26, 99-107.

Ohta, H. \& Hattori, T. (1983a). Oligotrophic bacteria on organic debris and plant roots in a paddy field soil. Soil Biol Biochem 15, 1-8.

Ohta, H. \& Hattori, T. (1983b). Agromonas oligotrophica gen. nov., sp. nov., a nitrogen-fixing oligotrophic bacterium. Antonie Van Leeuwenhoek 49, 429-446.

Pearson, W. \& Lipman, D. (1988). Improved tools for biological sequence comparison. Proc Natl Acad Sci U S A 85, 2444-2448.

Saito, H. \& Miura, K. (1963). Preparation of transforming deoxyribonucleic acid by phenol treatment. Biochim Biophys Acta 72, 619-629.

Saitou, N. \& Nei, M. (1987). The neighbor-joining method: a new method for reconstructing phylogenetic trees. Mol Biol Evol 4, $406-425$.
Shindo, H. \& Kuwatsuka, S. (1977). Behavior of phenolic substances in the decaying process of plants. VI. Changes in quality and quantity of phenolic substances in the decaying process of rice straw in a soil. Soil Sci Plant Nutr 23, 319-332.

Suwa, Y. \& Hattori, T. (1984). Effects of nutrient concentration on the growth of soil bacteria. Soil Sci Plant Nutr 30, 397-403.

Takeuchi, M., Sakane, T., Yanagi, M., Yamasato, K., Hamana, K. \& Yokota, A. (1995). Taxonomic study of bacteria isolated from plants: proposal of Sphingomonas rosa sp. nov., Sphingomonas pruni sp. nov., Sphingomonas asaccharolytica sp. nov., and Sphingomonas mali sp. nov. Int J Syst Bacteriol 45, 334-341.

Takeuchi, M., Hamana, K. \& Hiraishi, A. (2001). Proposal of the genus Sphingomonas sensu stricto and three new genera, Sphingobium, Novosphingobium and Sphingopyxis, on the basis of phylogenetic and chemotaxonomic analyses. Int J Syst Evol Microbiol 51, 1405-1417.

Thompson, J. D., Higgins, D. G. \& Gibson, T. J. (1994). CLUSTAL W: improving the sensitivity of progressive multiple sequence alignment through sequence weighting, position-specific gap penalties and weight matrix choice. Nucleic Acids Res 22, 4673-4680.

Whang, K. \& Hattori, T. (1988). Oligotrophic bacteria from rendzina forest soil. Antonie Van Leeuwenhoek 54, 19-36.

Williams, S. T. (1985). Oligotrophy in soil: fact or fiction? In Bacteria in their Natural Environments, pp. 81-110. Edited by M. Fletcher \& G. D. Floodgate. Orlando, FL: Academic Press.

Yabuuchi, E., Yano, I., Oyaizu, H., Hashimoto, Y., Ezaki, T. \& Yamamoto, H. (1990). Proposals of Sphingomonas paucimobilis gen. nov. and comb. nov., Sphingomonas parapaucimobilis sp. nov., Sphingomonas yanoikuyae sp. nov., Sphingomonas adhaesiva sp. nov., Sphingomonas capsulata comb. nov., and two genospecies of the genus Sphingomonas. Microbiol Immunol 34, 99-119. 